\title{
Innovation in the First Mission of Universities
}

\author{
Loreto Fernández \\ loreto.fernandez@usc.es | University of Santiago de Compostela, Spain, Facultad de CC, Económicas, \\ Avda. do Burgo s/n, 15782 Santiago de Compostela, Spain \\ Sara Fernández-López \\ sara.fernandez.lopez@usc.es | University of Santiago de Compostela - Fac. CC. EE. EE. -15.782 \\ Santiago de Compostela (Spain) \\ Lucía Rey-Ares \\ lucia.rey.ares@udc.es | Department of Business, University of A Coruña \\ María Bobillo \\ m.bobillovarela@gmail.com | GEM Galicia Team, University of Santiago de Compostela
}

\begin{abstract}
There is an extensive literature on characteristics of "entrepreneurial" or "innovative" universities. As both terms have generally been used to refer to the same condition, different rankings of entrepreneurial universities use indicators universally recognized for innovative activity and primarily related to research and knowledge transfer (scholarly production, patents granted and licensed, number of firms created to exploit research results, etc.). Innovation is essentially grounded in an entrepreneurial mentality, but an innovative university (hereafter, IU) is one that transmits this mentality to all of its members, including the foremost among its central missions: education. The IU is a university that becomes a driver of economic and social development in the region in which it is established, seeking to improve society through knowledge. In recent years, various attempts have been made to "measure" this innovative/entrepreneurial character in a more technical way. In a prior study, we proposed a characterization of an entrepreneurial and innovative university. Here, we build on that study to define the IU. The originality of this proposal stems from its inclusion of the so-called third and fourth missions (knowledge transfer and social responsibility, respectively) as transversal elements implicit in the university's two central missions. In an IU, therefore, the university's relationship with and impact on its surrounding agents are essential aspects entwined with its two basic functions.
\end{abstract}

Keywords. Entrepreneurial university; Innovative university; Entrepreneurial HE.

Cite paper as: Fernández, L., Fernández-López, S., Rey-Ares , L., Bobillo, M., (2018). Innovation in the First Mission of Universities, Journal of Innovation Management, www.open-jim.org, 6(4), 32-48. http://hdl.handle.net/10216/118596; DOI: https://doi.org/10.24840/2183-0606_006.004_0004 


\section{Introduction}

In recent years, higher education has undergone many radical changes. "Rupture factors" are transforming the environment in which universities develop their activity and directly influence the way they perform their two central functions: education and research. New teaching methodologies that combine formal and informal education have arisen, using technological and collaborative tools like the flipped classroom, expanded education, service learning and Massive Open Online Courses (MOOCs). New ways of competing have also emerged among providers of higher education, not only private universities but also corporate universities created directly by a company to improve future professionals who will be integrated into the sector and, most likely, into the firm itself.

New forms of accountability and evaluation of universities' performance have also appeared conditioning the decisions about the institution's strategy. International rankings are a good example. They aim to measure universities' performance through criteria based in most cases on quantitative indicators with values that very few institutions can achieve. In so doing, rankings usually put the emphasis on some university activities such as scholarly production, patents granted and licensed, or number of spin-off firms created, among others. As the importance of these rankings has increased and this expansion has taken the form of an increasingly discriminatory factor, universities have struggled to promote themselves as "entrepreneurial universities", given that many of the aforementioned activities have an entrepreneurial base.

In this paper we argue that this approach is to some extent a short-sighted view of the universities' functions. First, the most used international rankings tend to push de first mission of universities (education) into the background in favour of the second mission (research). However, universities can also create value to society by educating. Second, the conceptualization of a university as entrepreneurial is to some extent limiting.

In this study we address both questions. Thus, based on the models of entrepreneurial universities, we characterize "innovative universities" (hereafter, IUs) as those institutions that translate a transformative vision, attitude, and vocation to all of their functions, becoming drivers of economic and social change in their area of influence. Unlike the entrepreneurial term, the innovative term is bigger in scope and covers the two university's missions. Then, we present some examples of innovation in the first mission of the university in order to show how innovation in education can also strengthen the institutions' entrepreneurial profile.

Section 2 stresses the changes in the production model of university knowledge. It is precisely these changes aimed at increasing connection to the socioeconomic environment which have led universities to the new institutional "paradigm" of the entrepreneurial universities. Section 3 reviews the models that have emerged in recent years to measure the entrepreneurial dimension of universities. Based on these models we propose the conceptualization of IUs in Section 4. Focusing on the first mission (education) and on recent success stories of IUs, Section 5 shows some IUs' practices. Finally, in Section 6 we establish the main conclusions, limitations, and future lines of research. 


\section{Evolution of the cardinal functions of the university}

In recent years, the university as institution has undergone a significant evolution -some would say revolution- in its cardinal functions (see Figure 1). In the 1990s, a new dynamic was established in scholarship and research, termed Mode 2 by Gibbons et al. (1994). In contrast to the traditional model of scholarly knowledge production (Mode 1), the new model focuses on the context in which university is located; that is, knowledge is produced to cover the explicit needs of an external agent -industry or government following the Triple helix model proposed by Etzkowitz and Leydesdorff (2000)-. This transformation, which Etzkowitz (1990) compares to a second academic revolution, leads to the university's adoption of the so-called "third mission", which covers all activities related to the generation, use, application, and exploitation outside academia of the knowledge and other capacities that universities possess (Molas-Gallart et al., 2002).

Fulfilling this third mission has made the university a decisive actor in the economic and social development, strengthening connections between the different agents in its environment. Such connections not only generate a more democratic access to university knowledge but also invigorate innovation processes exponentially (Carayannis \& Campbell, 2009). Above all, they give rise to new relationships for the production of knowledge, termed Mode 3.
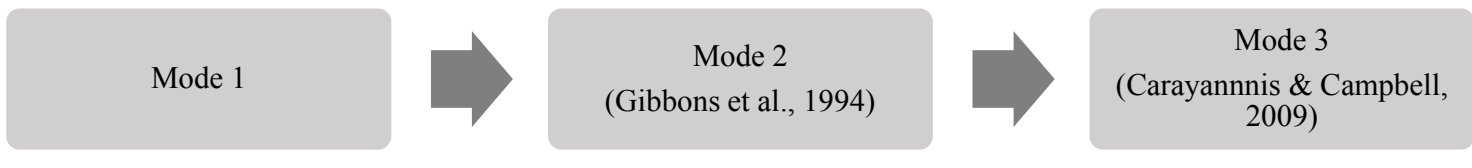

$$
\begin{aligned}
& 1^{\text {st }} \text { Mission: education } \\
& 2^{\text {nd }} \text { Mission : knowledge } \\
& \text { production }
\end{aligned}
$$
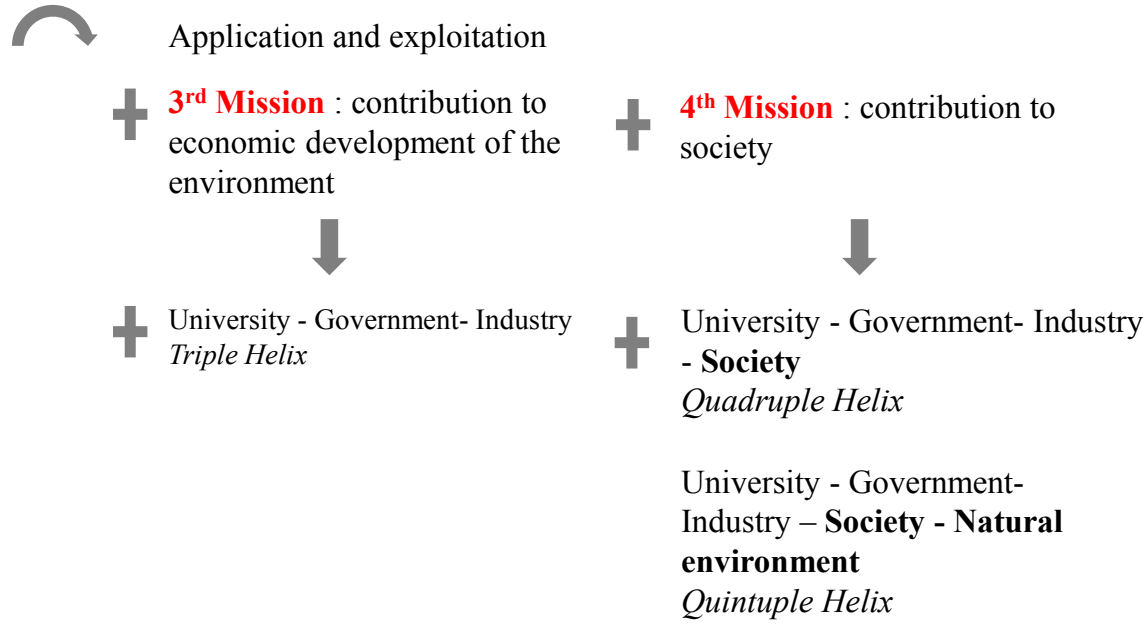

Fig. 1. Evolution of the cardinal functions of the university. SOURCE: developed by the authors based on Fernández et al. (2017)

Mode 3 of knowledge production also operates in a context of application, but here apart from government and industry the demands also comes from social actors (communication media, culture, and civil society) and the natural environment of society, composing the Quintuple helix 
model. Thus, research activity seeks not only to be productive but also to respond to humanity's problems and the communities afflicted by them (Carayannis et al., 2012).

In this new context, knowledge transfer and business incubation cease to be casual and become permanent activities that occur in all strata of the university. Thus, "effective linking of the university to the socioeconomic environment -including companies- generates a virtuous circle, in which firms benefit from greater competitiveness and universities perceive the benefits of integration into society through a new social contract. This contract contrasts with the previous one by requiring greater direction of research activities toward social needs" (Castro \& Vega, 2009, p.73).

Although this focus has not escaped criticism (i.e., threat to university autonomy; research oriented only to activities with potential for economic use, to the detriment of open development of knowledge, etc.), we entered the new millennium with a renewed university, whose functions involve continuous interactions with external agents to directly contribute to the economic and social development of the context in which the university evolves (Chrisman et al., 1995; Etzkowitz \& Klofsten, 2005).

\section{From the entrepreneurial university to the innovative univer- sity}

Yusof \& Jain (2010) distinguish three main streams of literature that have emerged with the aforementioned evolution of the university' functions: Entrepreneurial University, Academic Entrepreneurship and Technology Transfer. Given that our study falls into the first stream, we focus on the studies that address the topic of entrepreneurial university.

In the literature there is a wide range of definitions of an entrepreneurial university ${ }^{1}$. But more important than these attempts to conceptualize the term are those focused on measuring the entrepreneurship level of universities. Indeed, as the use of the term has spread and political and university leaders have trusted on universities as a source of innovation and entrepreneurship, various models to "measure" these entrepreneurial activities in a more technical way have arisen. These models are relatively recent and try to capture the entrepreneurship level of universities by distinguishing different courses of action (dimensions) within the universities (for more detail, see Fernández et al. [2017]). Table 1 contains a comparative summary of the most widely tested models.

After reviewing the dimensions of the models in Table 1, as well as the indicators of each dimension (see Fernández et al., 2017), we conclude that the characteristics used to label universities as "entrepreneurial" are actually universally recognized indicators of "innovative activity". This "overlap" is understandable since, in academia, the concept of entrepreneurship is closely tied to innovation. As early as the 1980s, Drucker (1985) argued that innovation in organizations is driven by those who think, behave, and act in an entrepreneurial way.

$1 \quad$ For an exhaustive review, see Yusof \& Jain (2010). Kirby et al. (2011) also analyze the most widely-used definitions and characteristics that have achieved greater consensus. 
Table 1. Models that identify the entrepreneurial profile of a university: comparative analysis

\begin{tabular}{|c|c|c|c|c|c|}
\hline MODEL & $\begin{array}{l}\text { Leading the } \\
\text { En- } \\
\text { trepreneurial } \\
\text { University }\end{array}$ & $\begin{array}{l}\text { Creating } \\
\text { university- } \\
\text { based } \\
\text { entrepre- } \\
\text { neurial } \\
\text { ecosystems }\end{array}$ & HEInnovate & $\begin{array}{l}\text { Entrepre- } \\
\text { neurial } \\
\text { University } \\
\text { Accreditation }\end{array}$ & $\begin{array}{l}\text { Entrepre- } \\
\text { neurial } \\
\text { Universi- } \\
\text { ties } \\
\text { Index }\end{array}$ \\
\hline $\begin{array}{l}\text { AUTHOR/ } \\
\text {-S (YEAR) }\end{array}$ & $\begin{array}{l}\text { Gibb et } \\
\text { al.(2012) } \\
\text { National } \\
\text { Centre for } \\
\text { Entrepreneur- } \\
\text { ship in } \\
\text { Education } \\
\text { (NCEE) }\end{array}$ & $\begin{array}{l}\text { Graham (2014) } \\
\text { MIT Skoltech } \\
\text { Initiative }\end{array}$ & $\begin{array}{l}\text { European } \\
\text { Commission } \\
(2011)\end{array}$ & $\begin{array}{l}\text { Accreditation } \\
\text { Council for } \\
\text { Entrepreneurial } \\
\text { and Engaged } \\
\text { Universities } \\
\text { ACEEU (2016) }\end{array}$ & $\begin{array}{l}\text { Júnior } \\
\text { Brasil, } \\
\text { AIESEC, } \\
\text { Rede CsF, } \\
\text { Enactus \& } \\
\text { Brasa } \\
(2016)\end{array}$ \\
\hline SCOPE & National & Global & European & Global & National \\
\hline $\begin{array}{l}\text { TYPE OF } \\
\text { INDICA- } \\
\text { TOR }\end{array}$ & $\begin{array}{l}\text { Primarily } \\
\text { qualitative }\end{array}$ & & $\begin{array}{l}\text { Quantitative } \\
\text { and qualitative }\end{array}$ & $\begin{array}{l}\text { Primarily } \\
\text { qualitative } \\
\text { (descriptive) }\end{array}$ & $\begin{array}{l}\text { Primarily } \\
\text { quantita- } \\
\text { tive }\end{array}$ \\
\hline $\begin{array}{l}\text { METHO- } \\
\text { DOLOGY }\end{array}$ & & $\begin{array}{l}\text { Surveys of } \\
\text { experts; visits; } \\
\text { public } \\
\text { information } \\
\text { available }\end{array}$ & $\begin{array}{l}\text { Self-evaluation. } \\
\text { Surveys of } \\
\text { different groups } \\
\text { from the } \\
\text { university } \\
\text { community }\end{array}$ & $\begin{array}{l}\text { External } \\
\text { evaluation } \\
\text { organism }\end{array}$ & $\begin{array}{l}\text { Index for } \\
\text { developing } \\
\text { university } \\
\text { rankings }\end{array}$ \\
\hline \multirow[t]{5}{*}{$\begin{array}{l}\text { DIMEN- } \\
\text { SIONS }\end{array}$} & \multirow[t]{2}{*}{$\begin{array}{l}\text { Mission, } \\
\text { government, } \\
\text { and strategy }\end{array}$} & $\begin{array}{l}\text { Leadership and } \\
\text { institutional } \\
\text { policies }\end{array}$ & $\begin{array}{l}\text { Leadership and } \\
\text { governance }\end{array}$ & $\begin{array}{l}\text { Orientation and } \\
\text { strategy }\end{array}$ & \\
\hline & & $\begin{array}{l}\text { Entrepreneurial } \\
\text { culture }\end{array}$ & $\begin{array}{l}\text { Organizational } \\
\text { capacity: } \\
\text { financing, } \\
\text { people, and } \\
\text { incentives }\end{array}$ & $\begin{array}{l}\text { Entrepreneurial } \\
\text { culture, } \\
\text { human, and } \\
\text { organizational } \\
\text { capital }\end{array}$ & $\begin{array}{l}\text { Entrepre- } \\
\text { neurial } \\
\text { culture }\end{array}$ \\
\hline & \multirow[t]{2}{*}{$\begin{array}{l}\text { Entrepre- } \\
\text { neurial } \\
\text { education }\end{array}$} & $\begin{array}{l}\text { Entrepre- } \\
\text { neurship } \\
\text { activities and } \\
\text { leadership in } \\
\text { innovation }\end{array}$ & $\begin{array}{l}\text { Teaching and } \\
\text { learning }\end{array}$ & \multirow[t]{3}{*}{$\begin{array}{l}\text { Education, } \\
\text { research, and } \\
\text { transfer }\end{array}$} & \\
\hline & & & $\begin{array}{l}\text { Preparation } \\
\text { and support for } \\
\text { entrepreneurs }\end{array}$ & & \\
\hline & & $\begin{array}{l}\text { Entrepreneurship } \\
\text { activities and } \\
\text { student-led } \\
\text { innovation }\end{array}$ & & & \\
\hline
\end{tabular}




\begin{tabular}{|c|c|c|c|c|c|}
\hline MODEL & $\begin{array}{l}\text { Leading the } \\
\text { En- } \\
\text { trepreneurial } \\
\text { University }\end{array}$ & $\begin{array}{l}\text { Creating } \\
\text { university- } \\
\text { based } \\
\text { entrepre- } \\
\text { neurial } \\
\text { ecosystems }\end{array}$ & HEInnovate & $\begin{array}{l}\text { Entrepre- } \\
\text { neurial } \\
\text { University } \\
\text { Accreditation }\end{array}$ & $\begin{array}{l}\text { Entrepre- } \\
\text { neurial } \\
\text { Universi- } \\
\text { ties } \\
\text { Index }\end{array}$ \\
\hline & \multirow{2}{*}{$\begin{array}{l}\text { Knowledge } \\
\text { exchange and } \\
\text { support for } \\
\text { knowledge } \\
\text { transfer }\end{array}$} & & \multirow{2}{*}{$\begin{array}{l}\text { Knowledge } \\
\text { exchange and } \\
\text { collaboration. } \\
\text { Measurement of } \\
\text { impact }\end{array}$} & \multirow{2}{*}{$\begin{array}{l}\text { Innovation and } \\
\text { impact }\end{array}$} & Scope \\
\hline & & & & & Innovation \\
\hline & \multirow{2}{*}{$\begin{array}{l}\text { Relationships } \\
\text { with local } \\
\text { and national } \\
\text { stakeholders }\end{array}$} & \multirow{2}{*}{$\begin{array}{l}\text { Relationship } \\
\text { and support } \\
\text { provided by the } \\
\text { external } \\
\text { community at } \\
\text { regional, } \\
\text { national, and } \\
\text { international } \\
\text { level }\end{array}$} & & & $\begin{array}{l}\text { Infra- } \\
\text { structures }\end{array}$ \\
\hline & & & & & $\begin{array}{l}\text { Financial } \\
\text { capital }\end{array}$ \\
\hline & $\begin{array}{l}\text { Internationali- } \\
\text { zation }\end{array}$ & & $\begin{array}{l}\text { Internationali- } \\
\text { zation }\end{array}$ & & $\begin{array}{l}\text { Internationa- } \\
\text { lization }\end{array}$ \\
\hline
\end{tabular}

SOURCE: developed by the authors based on Fernández et al. (2017)

Then, in this paper we argue that conceptualization of a university as "entrepreneurial" is to some extent limiting. Whereas entrepreneurship is associated with setting up an activity, innovating is connected to the profitable application of something new. The concept of innovation is thus broader and richer in nuance than that of entrepreneurship, since innovation involves a change in the "way of doing things", the setting up of a novel initiative, and the effectiveness of this initiative in fulfilling the objectives proposed (i.e. profitability).

In the following, using the dimensions of the models in Table 1 we identify the dimensions that characterize an IU. More specifically, two main reasons lead us to select the model proposed by Gibb et al. (2012) as a starting point. First, this model has been applied in a practical way for the development of the program Entrepreneurial University Leaders, launched by Oxford University's Saïd Business School in 2010. Second, the dimensions indicated by Gibb et al. (2012) are used in all the remaining models, revealing five strategic areas:

1. Institutional leadership and governance. There is almost unanimous consensus about the role played by the university governance leadership in entrepreneurship and innovation; it is hard to be considered an IU without a determined, clear institutional stake in this objective. The importance of this aspect generally stems from the fact that IUs have been driven by governance teams committed to this objective.

Regarding this dimension, the innovative profile of the university depends on its commitment to issues such budgetary resources allocated, corporate image and measurement of excellence, strategy in entrepreneurship and innovation in the institution's annual activities plan, flexibility, and speed in responding to the different setbacks and situations 
that arise in day-to-day functioning, etc. Similarly, all rankings that identify the most exceptional universities worldwide recognize governance as a key driver of the universities' performance $^{2}$ (Salmi, 2013).

2. Educational design and teaching and learning system. This dimension refers to promoting innovative teaching activities that complement comprehensive education of both students and other members of the university community. It can be led both by the institution itself and by other groups in the ecosystem (i.e. industry). The importance of this dimension lies in the university's capacity to provide an entrepreneurial and innovative educational program. Such a program should include not only formal training but also nonformal complementary training activities proposed by the teaching and research faculty (TRF), students, and even administrative and service personnel (ASP). It also should recognize prior experience in entrepreneurship and innovation when hiring and promoting $\mathrm{TRF}$ or in the academic record of students.

It is noteworthy that this dimension emphasizes not only teaching but also learning, which requires the individual's active participation in the educational activity. This approach involves considering as a result of IUs not only the spin-offs that arise from knowledge/technology generated/ developed through research activity (a traditional view of the function of "knowledge transfer"), but also the startups that emerge from the knowledge acquired during a university education that prepares the student to engage in future entrepreneurial projects.

3. Research, $R \mathscr{G} D$ model, and knowledge transfer. This dimension includes activities related to research, R\&D and knowledge transfer. This is the dimension most traditionally used when speaking of entrepreneurial universities for two main reasons. First, because it is through research that new knowledge emerges, and then will be transformed into innovations to reach society through various mechanisms of technology transfer (e.g., patents, licensing contracts, or spin-offs, among others); and, second, because these results can be measured through classic indicators used globally to measure the university's innovative performance. Indeed, the importance of this dimension stems from the quantitative nature of these indicators. On rare occasions, however, they have been weighted according to the institution size, a practice that causes some inequality in some rankings. Further, when measuring scholarly production and technology transfer, one must consider activity financed not only with public funds but also with private capital, demonstrating the interest that the university awakens among the other agents in the ecosystem, particularly industry.

4. Relationships with other stakeholders in the environment. This dimension puts the emphasis on the university's links to agents in its environment; that is, its stakeholders, whether members of the academic community itself or external to the university (Figure 2 ). These linkages may be greater or lesser in scope based on various factors, such as size and historical development of the university, or the economic and social circumstances of its context. Thus, the "sphere of influence" of a university reflects its vocation to impact the community, whether at a local, regional, national, or even international level.

$2 \quad$ Understood as the set of structures, processes, and activities involved in planning and orienting the institution and agents that work in the system. 
In any case, as a key agent of the ecosystem, the university's relationship with the other agents is not only crucial but indispensable to its success. Thus, all of the university's functions must consider this necessary relationship of knowledge transfer, which is achieved through relationships maintained with diverse stakeholders, which in turn provide their support through various mechanisms (e.g., contracts and collaboration agreements, financing, etc.).

5. Internationalization. Degree of openness to its environment is another major dimension that defines the entrepreneurial and innovative profile of universities. As suggested in Point 4, internationalization indicates an extension of the relationships the institution maintains with agents in its environment beyond national borders. In an increasingly global world, all universities develop policies to establish agreements with entities from other countries that reflect the importance of granting their functions in the field of education and research an international dimension.

\begin{tabular}{|l|}
\hline \multicolumn{1}{|c|}{ Internal } \\
(temporarily form part of the \\
academic community)
\end{tabular}

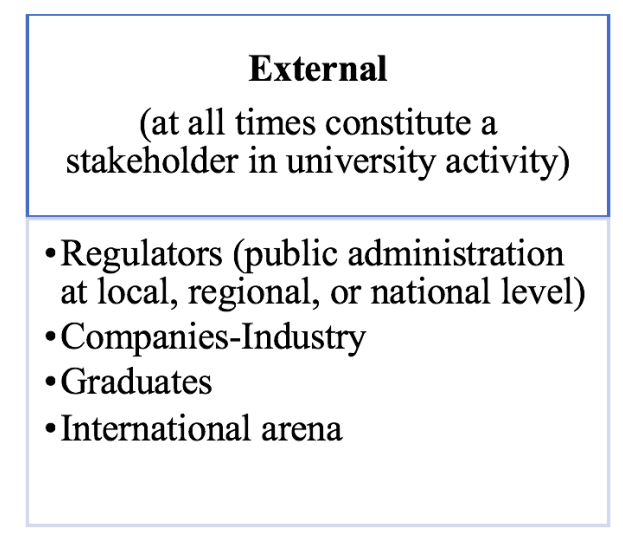

Fig. 2. Stakeholders in the university environment. SOURCE: developed by the authors

\section{Characterizing the innovative university}

As we mentioned, after reviewing the courses of action included in each of five dimensions of an entrepreneurial university, we can appreciate that most of them refer to innovative activities rather than to entrepreneurial activities. Then, based on these dimensions, in this section we propose a definition of the IU. Although this proposal includes the aforementioned dimensions (Figure 1), the last two ones -university's linkages with its environment and degree of internationalization- are considered a transversal element that modulates the impact of the two core functions (missions) of a university (education and research), rather than dimensions themselves.

An IU must start from institutional leadership provided by its governance model (Dimension 1) and develop a strategy for innovation in the areas of teaching and learning (Dimension 2) and/or research and knowledge transfer (Dimension 3). At the same time, this strategy must include the knowledge transfer to society through the (two-way) relationships established with the agents in 
the university's closest environment (local, regional or national) and international environment (an element implicit in the three previous dimensions).

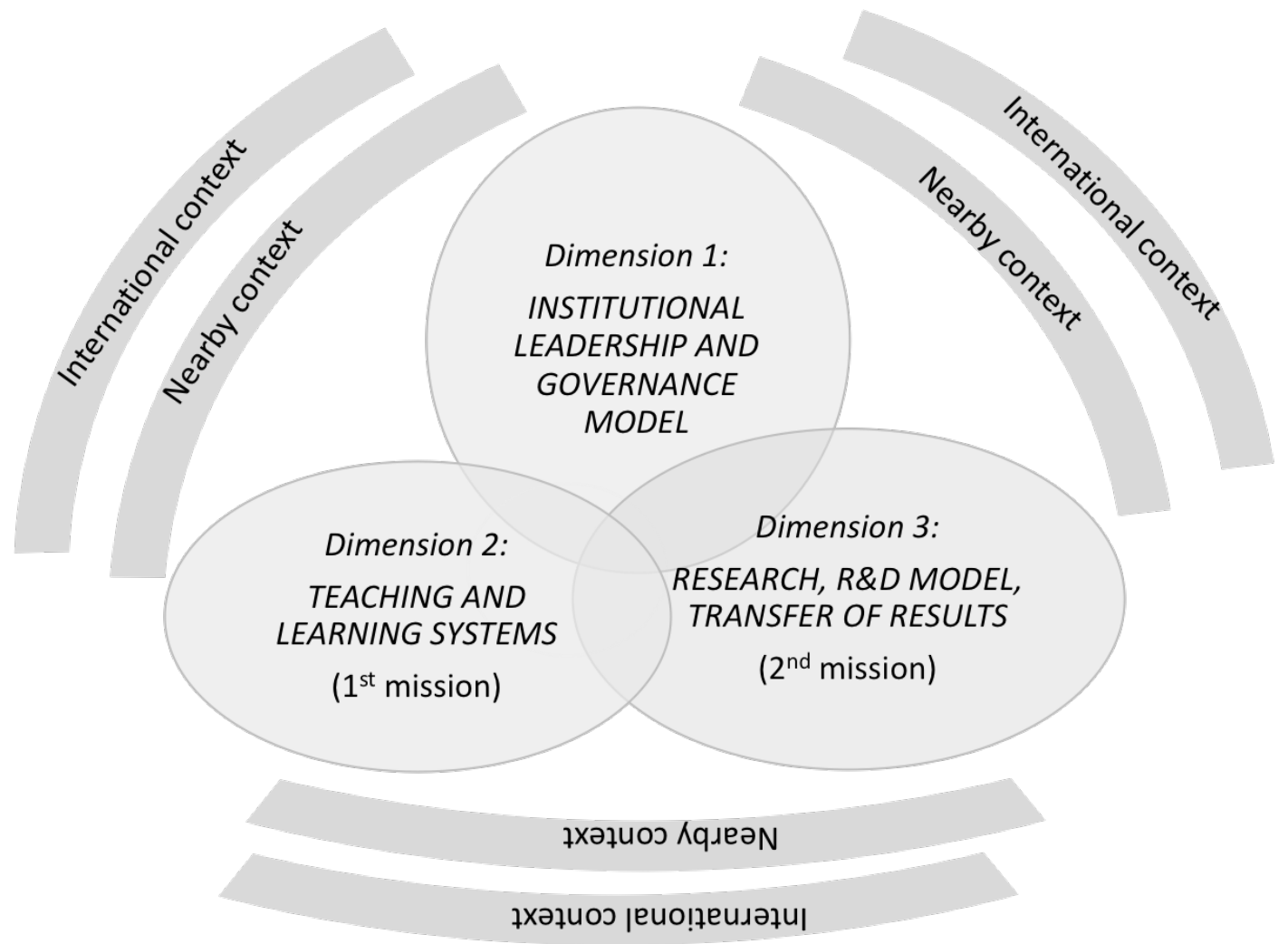

Fig. 3. Key areas of the profile of an IU. SOURCE: developed by the authors

This approach considers IUs as institutions that contribute through permanent innovation to the development and improvement of society through knowledge (Barro, 2017), whether creating knowledge (second mission: research) or disseminating it (first mission: education). This definition implies that knowledge transfer to society and permanent relationships with agents in the university's environment are at the root of all IUs, since both elements ground the IU's existence. Internationalization is thus no more than the expression of these relationships when they extend beyond national borders. The so-called third mission of the university, and even what has most recently been termed the fourth mission derived from its responsibility for society, would be already included in the first two central missions of the academic institution -education and research-; they cannot be understood without this transversal aspect, which assumes the link to their economic and social environment.

\section{Some examples}

In this section, we present four examples of innovation in the first mission of the university in order to show how innovation in education can also strengthen the institutions' entrepreneurial 
profile. Thus, within Dimension 2, we find various institutions that correspond to the definition of IU. These are universities whose teaching-learning systems are developing strategies, programs, or initiatives that not only manage to achieve the goals of improvement for which they were designed, but they can also become sustainable long-term benchmarks for replication in other environments. In selecting them, we opt for a geographical range to show that one can find examples of the concept of IU in more- and less-developed environments, and in entities with longer or shorter histories, since the priority is the role of the university as a key agent in the economic development of the area and its capacity to respond to the real, specific demands of society $^{3}$. In Figure 4 we position these four examples in the dimensions of an IU.

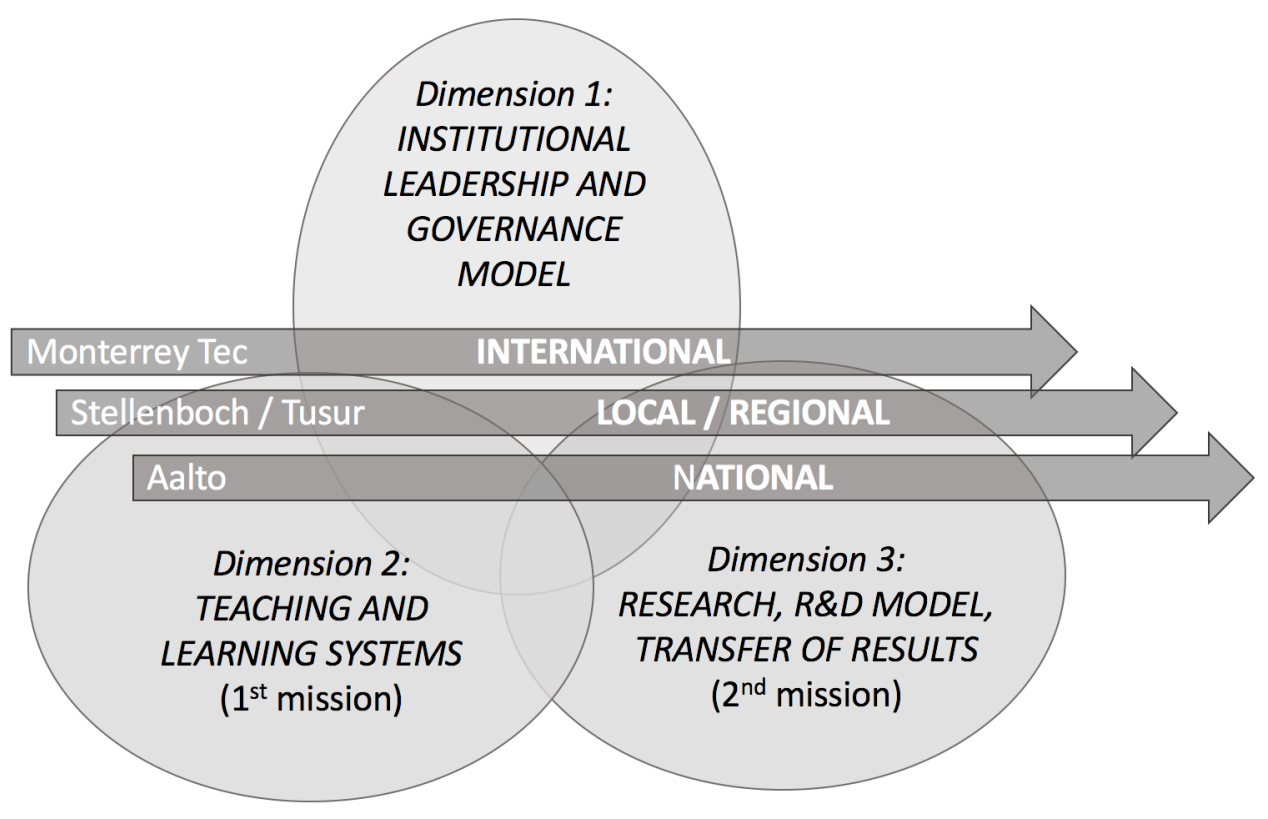

Fig. 4. Positioning of the analyzed universities in the dimensions of an IU. SOURCE: developed by the authors

The first case is Russia's Tomsk State University of Control Systems and Radioelectronics (TUSUR). TUSUR was founded in 1962 by removing two departments of Tomsk Polytechnic University, composed at that time of especially young professors with initiative. Specializing in Engineering, particularly in the fields of robotics and technological innovation, TUSUR was a pioneer in establishing methods of project-based group learning to enable students to develop teamwork competences while performing R\&D studies. Participating in this type of project is an integral part of the education process; in the course of such training students' ideas advance through all stages of the development process, from technical assignment to the pilot project. The measure was also supported by the national government.

The case of Stellenbosch University (South Africa) shows that tradition does not conflict with innovative activity. Although the country's oldest university (founded in 1866), Stellenbosch implements some practices in academic innovation that are significant for its consideration as an IU. At the Rural Ukwanda Clinical School of the Faculty of Medicine and Health Sciences,

3 Information drawn from the universities themselves and in some cases from Graham (2014). 
inaugurated in 2012, students may complete their clinical training in a rural environment where health care is scarce, thus meeting a real demand in this university's specific environment. This action was possible thanks to the university government's firm commitment to other agents operating in the same environment who composed an ecosystem of emerging innovation.

Monterrey Institute of Technology and Higher Education is a private, non-profit institution founded in 1943 by a group of businesspeople who were then members of the civil association "Teaching and Higher Education". The Institute's activity, developed across various campuses, is supported by civil associations composed of a large group of prominent leaders throughout the country who are committed to the quality of higher education. Its bid to become a driver of community development is based largely on the educational dimension. In 2012, the Institute initiated a new educational model, TEC21, based on innovative experiences and challenges and active learning spaces. "Challenge-based learning" is an educational model that exposes the student to real problems in the environment, helping him/her to develop entrepreneurial competences and human sensibility. The model also involves experiential, collaborative learning that unifies knowledge, providing the student maximum flexibility in the study program: which subjects to take, and how, when, and where to develop his/her professional training process. The model incorporates technology into the teaching process and involves instructors actively in students' professional, business, academic, and social environment as guides for students' learning.

Finally, a case that merits special recognition is Aalto University (Finland), which began its professional activity in 2010, after the merger of three institutions: Helsinki School of Economics, Helsinki University of Technology, and Helsinki University of Art and Design. Located in the city of Espoo (Otaniemi-Finland), a region with a large number of research centers and higher education institutions, Aalto University emerged as an IU fostered fundamentally by the entrepreneurial movement led by its students. The movement originated in a group of Master's students at Helsinki School of Economics who visited the U.S. to get to know its student entrepreneurship societies. The students became aware of the need to lead a movement to foster entrepreneurial initiatives in Finland. In 2009, this movement began to take the first steps to organize public events and to involve the community of local startups and the university's leadership team in these events. This moment saw the creation of AaltoES, a non-profit corporation led by students and independent of the university, as well as Startup Sauna, also led by students and oriented to developing regional high-growth startups. Little by little, the university's top management developed a more innovative strategy, such that its vision "involves strong commitment to the construction of a sustainable society driven by innovation and business spirit" ${ }^{4}$. Once the leadership team became aware of this movement, it began to take its first steps, providing training in entrepreneurship throughout its centers.

Several conclusions can be drawn on the basis of the examples reviewed:

1. A good example of the interaction between academic training and support for social demands is the service-learning methodology, in which classroom learning is deepened by doing community services (Furco \& Billing, 2002). Students acquire knowledge, abilities, and values, working to address the real needs of the environment in order to improve it

$4 \quad$ Retrieved from http://www.aalto.fi/en 
(Puig et al., 2011). Applying this methodology shows that the educational dimension can have direct impact on the community (transversal aspect).

2. In all cases innovation emerges in the dimension of teaching and learning systems ( $d i$ mension 2). Thus, these universities are considered references in setting up new teaching methodologies -applying new pedagogical tools, technological innovations to improve training and preparation of students, or new approaches to instruction that enable academic learning while also attending to social demands-.

3. Universities increasingly understand the value of combining formal, or official, education with other forms of non-formal and informal learning ${ }^{5}$. To do so, they attempt to recognize other approaches to education that occur outside the classroom but can complement traditional teaching and greatly improve the quality of the education received. These forms of learning are especially useful in the area of entrepreneurial education because one very important part of the entrepreneur's training involves personal, social, and managerial abilities ("soft skills"). These abilities are hard to cover in formal education, since they require specific training that is often personal and individualized.

4. As can be observed in Figure 4, although the innovation emerges in the dimension 2, this dimension interacts with the other ones. Particularly, the institutional leadership and governance (dimension 1) plays a crucial role in all the mentioned examples, since the university's governance is aware of the needs in the closest environment and provides support for the initiatives both inside and outside the university. In addition, the involvement of the university's governance allows the recognition of this non-formal or informal learning in the students' curriculum. Moreover, in the particular case of Aalto and TUSUR the interactions also involve the dimension 3 since they have enabled the universities' technology transfer. This analysis supports the idea of that the different dimensions of an IU are not linear but interrelated amongst themselves.

5. The aforementioned innovations emerge for attending to social demands at a local (Stellenbosch), regional (TUSUR), national (Aalto) and international ${ }^{6}$ (Monterrey) levels.

In sum, the above mentioned examples show real cases in which teaching-learning systems ( $d i$ mension 2) has served as a catalyst in building an IU, permeating the other dimensions of the model and changing the entrepreneurial culture of the university staff and society as a whole.

\section{Conclusions}

The goal of this investigation has been to characterize a university as "innovative", as opposed to "entrepreneurial", the term most widely used to refer to specific universities but narrower in

\footnotetext{
$5 \quad$ Within formal education (which involves a deliberate, systematic intent specified in an official curriculum that occurs in a specific space and usually full-time study), we can even distinguish between non-formal education, which is associated with community groups and organizations, and civil society; and informal education, which covers everything else (interaction with friends, family members, colleagues, leaders, and teachers; self-learning; socialization; youth employment, leisure; etc.).

$6 \quad$ For the LATAM countries.
} 
scope. In this paper, we argue that it is more appropriate to speak of IUs, since innovation: 1) implies an entrepreneurial mentality and thus includes entrepreneurial universities in this category; 2) in contrast to entrepreneurship, always involves novelty, changing what one has been doing; and 3) also involves profitability, or returns for society. Our approach thus views the term IU as "guaranteeing" that a university engages in entrepreneurship, generating a return for the stakeholders with which it interacts.

In addition, we propose the dimensions in which a university can be innovative. Based on the literature reviewed, particularly on the model developed by Gibb et al. (2012), our proposal revolves around three interrelated dimensions. Specifically, we differentiate Dimension 1: institutional leadership and governance model, which in some way affects the university's governance team but also permeates the functioning of the whole institution. We also separate the two traditional missions of a university, education and research, into their own dimensions: Dimension 2: teaching and learning systems and Dimension 3: research, RESD model, and knowledge transfer. In any of these three areas, the university's interactions with the different stakeholders in its ecosystem (neighboring or international) is a key element, as interaction modulates the impact of the institution's educational and research model.

We thus conclude that the "third" and "fourth" missions of universities disappear as such, since they are mere extensions of the teaching and research responsibilities. In addition, all of the dimensions are interrelated; although each university's innovation begins in one of the three dimensions, it does not neglect the others, which are also permeated by this innovative character, making such university as a whole an innovative institution. More specifically, for the innovative process to succeed there must be interaction with Dimension 1; that is, a solid commitment of the institution's government to support the transformation process is required. Moreover, relationship to stakeholders in the environment (neighboring or international) is also crucial. This interaction must be two-way; innovations cannot be introduced neglecting society's opinion/needs. Although it is advisable to have the support of the stakeholders from the start, one must sometimes win this support based on a track record of small achievements.

Some examples of innovation in the first mission of the university, Dimension 2: teaching and learning systems, have been presented in order to show that innovations in this area can strengthen the institution's entrepreneurial profile. Further, although the aforementioned institutions do not usually appear in the classical international rankings of innovation (with the exception of Monterrey TEC), they are becoming internationally known as IUs thanks to specific actions. It is also noteworthy that these innovative practices do not always or necessarily involve the investment of large amounts of resources. Instead, they merely change what has been being done with existing resources. Such innovations can, however, bring significant returns for the institution and for society.

Thus, with the exception of Monterrey TEC, the universities analyzed are small compared to universities that traditionally lead the best-known rankings, but their role as drivers of change and socioeconomic development of the ecosystem in which they are situated has recently elevated them to high positions in alternative rankings. Aalto University, for example, was designated by 
the Massachusetts Institute of Technology (MIT) as one of the five "rising stars" in innovation" and selected as one of the top five millennial generation universities (created in 2000) by Times Higher Education ${ }^{8}$.

This investigation contributes in various ways to the literature on innovative universities. First, it establishes the paradigm of the IU as opposed to the entrepreneurial university, which is smaller in scope and focuses specifically on the university's second mission (research).

Second, this paper proposes a conceptualization of the IU around three dimensions, greatly simplifying existing approaches to measuring universities' innovative profile. In this approach, the university's missions are again reduced to two, education and research, which only make sense if carried out in contact with stakeholders to generate returns for society.

Third, we analyze in detail the innovations introduced by the IU in Dimension 2: teaching and learning systems. Although the results of transformations in this area emerge in the long term, making it harder to measure their impact on the environment, innovations in Dimension 2 have at least two important advantages over innovations in the other dimensions of the model. First, in contrast to innovations in Dimension 3: research, RED model and technology transfer, they do not require large investments. Second, in contrast to the innovations in Dimension 1: institutional leadership and governance model, they introduce "bottom-up" changes, generating deeper transformation that is more difficult to reverse in the institution's own culture.

Finally, this work also presents some limitations. In particular, the most outstanding of them being the need of validating in practice the proposed IU model by carrying out a case study, and not a simple presentation of examples. Therefore, as a future line of research we consider using this model in order to check its applicability and reliability when testing the existence of IUs.

Note $\mathcal{E}$ Acknowledgement. A previous version of this paper has been presented at the CEE?2017 (Conference on Entrepreneurship Education) held in Aveiro (Portugal), 14 September of 2017. The authors thank Professor Senén Barro Ameneiro for useful comments and helpful suggestions.

\section{References}

Accreditation Council for Entrepreneurial \& Engaged Universities (2016): Retrieved 4 April 2017, from https://www. aceeu.org/.

Barro, S. (2017): "Misión de la Universidad". In Universídad, expert group blog Studia XXI. http://www.universidadsi.es/mision-la-universidad/

Carayannis, E.G., Barth, T.D., \& Campbell, D.F.J. (2012): "The Quintuple Helix innovation

\footnotetext{
$7 \quad$ See: http://sciencebusiness.net/news/76653/Aalto-University-among-the-five-rising-stars-of-the-worldsleading-universities-says-MIT-study

8 See: https://www.timeshighereducation.com/student/best-universities/best-young-universities-2017millennials-generation-x-and-generation-y
} 
model: global warming as a challenge and driver for innovation", Journal of Innovation and Entrepreneurship, 1(2), 1-12. doi: 10.1186/2192-5372-1-2

Carayannis, E.G., \& Campbell, D.F.J. (2009): "'Mode 3' and the 'Quadruple Helix': toward a 21st century fractal innovation ecosystem", International Journal of Technology Management, 46 (3/4), 201-234. doi: 10.1504/IJTM.2009.023374

Castro, E., \& Vega, J. (2009): "Las relaciones universidad-entorno socioeconómico en el Espacio Iberoamericano del Conocimiento", Revista Iberoamericana de Ciencia, Tecnología y Sociedad, 4(12), 73-74.

Chrisman, J.J., Hynes, T., \& Fraser, S. (1995): "Faculty entrepreneurship and economic development: the case of the University of Calgary", Journal of Business Venturing, 10(4), 267-281. doi: 10.1016/0883-9026(95)00015-Z

Drucker, P. (1985): Innovation and Entrepreneurship. Practice and Principles. Harper and Row Publishers.

Etzkowitz, H. (1990): "The second academic revolution: The role of the research university in economic development". In: Cozzens, S., Healey, Rip, A., \& Ziman, J. (Eds.): The Research System in Transition, Kluwer Academic Publishers, Boston, pp. 109-124.

Etzkowitz, H., \& Klofsten, M. (2005): "The innovating region: toward a theory of knowledgebased regional development", R\&D Management, 35(3), 243-255. doi: 10.1111/j.1467-9310.2005.00387.x

Etzkowitz, H., \& Leydesdorff, L. (2000): "The dynamics of innovation: from National Systems and 'Mode 2' to a Triple Helix of university-industry-government relations", Research Policy, 29(2), 109-123. doi: 10.1016/S0048-7333(99)00055-4

European Commission (2011). HEInnovate Project. https://heinnovate.eu/en.

Fernández, L., Fernández, S., Rey, L., Zapata, G.A, \& Bobillo, M. (2017). "Universidades Emprendedoras e Innovadoras: una propuesta de caracterización". In: M. Carrilho et al. (Eds.): $7^{\text {th }}$ Conferência Ibérica de Empreendedorismo, pp. 222-233. ISBN: 978-989-97513-6-1. $7^{\text {th }}$ Conferência Ibérica de Empreendedorismo, 8-9 June, Esposende (Portugal).

Furco, A., \& Billing, S.H. (2002): Service-Learning. The Essence of the Pedagogy, Information Age Publishing, Greenwich.

Gibb, A.A. (2013): "Developing the entrepreneurial university of the future. Key Challenges, Opportunities and Responses", OECD, Paris.

Gibb, A.A., Haskins, G., Hannon, P., \& Robertson, I. (2012): "Leading the Entrepreneurial University. Meeting the Entrepreneurial Development Needs of Higher Education Institutions". Policy Paper, National Centre for Entrepreneurship in Education (NCEE), University of Oxford. Retrieved 3 May 2017, from www.ncee.org.uk

Gibbons, M., Limoges, C., Nowotny, H., Schwartzman, S., Scott, P., \& Trow, M. (1994): The new production of knowledge: the dynamics of science and research in contemporary societies. London: Sage Publications. 
Graham, R. (2014): Creating university-based entrepreneurial ecosystems: evidence from emerging world leaders. MIT Skoltech Initiative.

Júnior, AIESEC, Rede CsF, Enactus, \& Brasa (2016): Índice de Universidades Empreendedoras. Retrieved 4 April 2017, from: https://www.capes.gov.br/

Kirby, D.A., Guerrero, M., \& Urbano, D. (2011): "Making universities more entrepreneurial: development of a model", Canadian Journal of Administrative Sciences, 28(3), 302-316.

Molas-Gallart, J., Salter, A., Patel, P., Scott, A., \& Duran, X. (2002): "Measuring third stream activities. Final Report to the Russell Group of Universities", Final Report to the Russell Group of Universities, University of Sussex, Birmingham, April.

Puig, J.M., Gijón, M., Martín, X., \& Rubio, L. (2011): "Aprendizaje-servicio y Educación para la Ciudadanía", Revista de Educación, 45-67.

Salmi, J. (2013): "Formas exitosas de gobierno universitario en el mundo". Estudios de la Fundación CYD 03/2013.

Yusof, M., \& Jain, K.K (2010): "Categories of university-level entrepreneurship: a literature survey", International Entrepreneurship Management Journal, 6, 81-96. doi: 10.1007/s11365007-0072-x 


\section{Biographies}

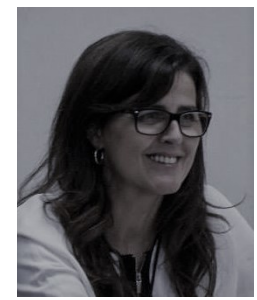

Loreto Fernández. Loreto Fernández Fernández was born in Silleda (Pontevedra, Spain) in 1963. She received the degree in Business Administration from the University of Santiago de Compostela (USC), Spain, in 1986. After a short research stage at School of Public and Environmental Affairs (Bloomington, IN, USA) in 1988, she made a doctoral programme in Entrepreneurship and Small Business Management at Durham University Business School (UK), and received the Ph.D. degree in Economics and Business Administration from USC, in 1996. She is a tenured professor in the Accounting and Finance Department, USC, since 1986. She held the Chair Bancaja "Young Entrepreneurs" at USC from 2007 to 2012, and the academic coordination of RedEmprendia from 2013 to 2016. She is the Director of the Galician research team of the Global Entrepreneurship Monitor Project (GEM) since 2015. Dr Fernández is the author of several chapters both in finance and entrepreneurship field, and more than 50 articles and contributions to national and international meetings. Her research interests include entrepreneurship and small firms finance, alternative financing and new business models at the circular economy sector.

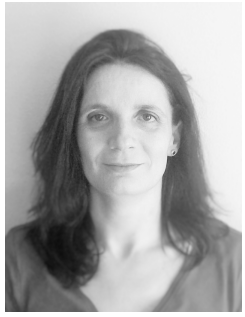

Sara Fernández-López. Sara Fernández-López was born in Villamartín de Valdeorras, Ourense, Spain in 1972. She received the degree in Business Administration from the University of Santiago de Compostela, A Coruña Spain, in 1995 and the Ph.D. degree in Economics and Business Sciences also from University of Santiago de Compostela, in 2001. Since 1996, she has been an Assistant Professor with the Accounting and Finance Department in the University of Santiago de Compostela. She is the author of more than ten books and more than 60 articles. Her research interests include technology transfer, technological and academic entrepreneurship, and personal finances. She is an Associate Editor (Finance) of the European Journal of Management and Business Economics. Ms Fernández's awards and honors include several Best Papers in Entrepreneurship and Accounting (Jornadas Luso-Espanholas. Gestão Científica) and the CEUSAL Award (2015) to the best thesis on Entrepreneurship. supervised by Fernández.

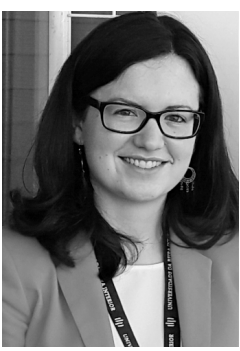

Lucía Rey-Ares . Lucía Rey-Ares was born in Boimorto, A Coruña, Spain. She holds a B.A. degree in Economics and a M.A. degree in Business Administration (MBA) from the University of Santiago de Compostela (A Coruña, Spain). In July 2018 she was awarded a PhD degree from the same institution. In September 2018 she joined the University of A Coruña (Spain), as an Assistant Professor in the Department of Business (business organization area). She has published several articles and book chapters. Her research interests include household finances and entrepreneurship. Ms. Rey's awards include acknowledgments in international conferences related to entrepreneurship and innovation, as the Conferência sobre Educação para o Empreendedorismo or the $7^{\mathrm{a}}$ Conferência Ibérica de Empreendedorismo.

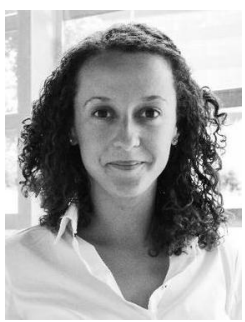

María Bobillo. María Bobillo was born in Ourense (Spain) in 1986. She holds a Degree is Business Administration from the University of Santiago de Compostela (USC), Spain. Since the begining of her professional career in 2012, she has been involved in several projects related to entrepreneurship and technology transfer initiatives within the university as project manager in Lisbon University Institute (Portugal) and RedEmprendia (Spain), among others. In addition, her research interests include women empowerment and European public policies. Nowadays, María works as a consultant on Public Sector policies. 